\title{
Using satellite data to identify the methane emission controls of South Sudan's wetlands
}

\author{
Sudhanshu Pandey ${ }^{1}$, Sander Houweling ${ }^{1,2}$, Alba Lorente ${ }^{1}$, Tobias Borsdorff ${ }^{1}$, Maria Tsivlidou ${ }^{3}$, A. Anthony Bloom ${ }^{4}$, \\ Benjamin Poulter ${ }^{5}$, Zhen Zhang ${ }^{6}$, and Ilse Aben ${ }^{1}$ \\ ${ }^{1}$ Earth Group, SRON Netherlands Institute for Space Research, Utrecht, the Netherlands \\ ${ }^{2}$ Department of Earth Sciences, Vrije Universiteit Amsterdam, Amsterdam, the Netherlands \\ ${ }^{3}$ Laboratoire d'Aérologie, Université de Toulouse, CNRS, IRD, UT3, Toulouse, France \\ ${ }^{4}$ Jet Propulsion Laboratory, California Institute of Technology, Pasadena, CA 91109, USA \\ ${ }^{5}$ NASA Goddard Space Flight Center, Greenbelt, MD 20771, USA \\ ${ }^{6}$ Department of Geographical Sciences, University of Maryland, College Park, MD 20740, USA
}

Correspondence: Sudhanshu Pandey (s.pandey@sron.nl)

Received: 2 July 2020 - Discussion started: 27 July 2020

Revised: 23 November 2020 - Accepted: 27 November 2020 - Published: 22 January 2021

\begin{abstract}
The TROPOspheric Monitoring Instrument (TROPOMI) provides observations of atmospheric methane $\left(\mathrm{CH}_{4}\right)$ at an unprecedented combination of high spatial resolution and daily global coverage. $\mathrm{Hu}$ et al. (2018) reported unexpectedly large methane enhancements over South Sudan in these observations. Here we assess methane emissions from the wetlands of South Sudan using 2 years (December 2017-November 2019) of TROPOMI total column methane observations. We estimate annual wetland emissions of $7.4 \pm 3.2 \mathrm{Tg} \mathrm{yr}^{-1}$, which agrees with the multiyear GOSAT inversions of Lunt et al. (2019) but is an order of magnitude larger than estimates from wetland process models. This disagreement may be explained by the underestimation (by up to 4 times) of inundation extent by the hydrological schemes used in those models. We investigate the seasonal cycle of the emissions and find the lowest emissions during the June-August season when the process models show the largest emissions. Using satellite-altimetry-based river water height measurements, we infer that this seasonal mismatch is likely due to a seasonal mismatch in inundation extent. In models, inundation extent is controlled by regional precipitation scaled to static wetland extent maps, whereas the actual inundation extent is driven by water inflow from rivers like the White Nile and the Sobat. We find the lowest emissions in the highest precipitation and lowest temperature season (June-August, JJA) when models estimate large emissions. In general, our
\end{abstract}

emission estimates show better agreement in terms of both seasonal cycle and annual mean with model estimates that use a stronger temperature dependence. This suggests that temperature might be a stronger control for the South Sudan wetlands emissions than currently assumed by models. Our findings demonstrate the use of satellite instruments for quantifying emissions from inaccessible and uncertain tropical wetlands, providing clues for the improvement of process models and thereby improving our understanding of the currently uncertain contribution of wetlands to the global methane budget.

\section{Introduction}

Reducing anthropogenic methane emissions has been recognized as an important requirement for achieving the 2015 Paris Agreement target of limiting global temperature rise to below $2{ }^{\circ} \mathrm{C}$ relative to pre-industrial times (Ganesan et al., 2019). However, large uncertainties remain in the atmospheric budget of methane, calling for an improved understanding of its emissions from both anthropogenic and natural sources (Saunois et al., 2016). Wetlands are ecosystems with seasonally or permanently inundated or saturated soils, including peatlands (bogs and fens), mineral wetlands (swamps and marshes), and seasonal or permanent floodplains, where methanogens produce methane in the anaero- 
bic decomposition of organic matter. Emissions from natural wetlands are the largest and most uncertain emission category of methane (Kirschke et al., 2013). Saunois et al. (2016) provide global methane emission estimates for all source categories combined of 540-568 $\mathrm{Tg} \mathrm{yr}^{-1}$ using top-down approaches and 596-884 $\mathrm{Tg} \mathrm{yr}^{-1}$ using bottom-up approaches for the period 2003-2012. They attribute the mismatch between the two approaches mainly to uncertainties in emissions from natural wetlands, inland waters and geological sources. They report total emissions of 127-202 and 153$227 \mathrm{Tg} \mathrm{yr}^{-1}$ from wetlands using top-down and bottom-up approaches, respectively, which accounts for $30 \%$ of global emissions.

In addition to being an important source of uncertainty in the methane budget, wetlands emissions can have significant climate feedback due to their sensitivity to changes in precipitation and temperature (Arneth et al., 2010; Zhang et al., 2018; Zhu et al., 2017). By analyzing surface and satellite measurements of methane, Pandey et al. (2017) reported enhanced methane emissions from tropical wetlands due to precipitation and temperature anomalies associated with the La Niña of 2010. Furthermore, according to Zhang et al. (2017), the feedback of methane should be accounted for in climate mitigation policies as they find that global wetland emissions will increase by 50 to $170 \mathrm{Tg} \mathrm{yr}^{-1}$ at the end of the 21 st century because of the temperature-driven increase in wetland emissions under the different Representative Concentration Pathways (RCPs) adopted by the IPCC. Their results indicate that the increase in wetland emissions may be $38 \%-56 \%$ larger than the projected anthropogenic emission increase by the end of the 21 st century under the strong climate mitigation scenario (RCP2.6).

Improving wetland emission estimates is very challenging for many reasons. Wetlands are spread over large, inaccessible regions around the world. Upscaling a few localized measurements of wetland emissions is often futile as these emissions have large temporal and spatial variability, and the parameters controlling them are very uncertain. The emissions are also difficult to monitor on the ground due to logistical limitations. This makes satellite observations a promising and crucial source of information to advance our understanding of the role of wetland methane emissions in the carbon cycle.

$\mathrm{Hu}$ et al. (2018) observed large methane enhancements over South Sudan in TROPOMI data collected during the first 2 months of the commissioning phase of the satellite in November and December 2017. Frankenberg et al. (2011) also observed an enhancement over the region in a 7-year average (2003-2010) of SCanning Imaging Absorption spectroMeter for Atmospheric CHartographY (SCIAMACHY) observations. These studies indicated that the enhancements are likely caused by large emissions from wetlands in the region. Recently, Lunt et al. (2019) used methane observations from the Japanese Greenhouse gases Observing Satellite (GOSAT) in inverse modeling to infer emissions from tropical Africa during 2010-2016. They found that emissions from South Sudan were more than 3 times larger than the ensemble mean estimates from the Wetcharts process model (Bloom et al., 2017). They also found that emissions from the Sudd wetlands in the region increased rapidly from 2.4$4.2 \mathrm{Tg} \mathrm{yr}^{-1}$ in $2010-2011$ to $5.2-6.9 \mathrm{Tg} \mathrm{yr}^{-1}$ in 2016 , likely because of an inundation extent expansion due to an increase in water inflow from the White Nile River.

This study aims to infer the scale of the wetland methane emissions from South Sudan from TROPOMI observations using a simplified emission quantification method and investigate its relationship to the results of wetland process models and seasonally varying climatological conditions. This study is structured as follows. Section 2 describes the method and data used, including the TROPOMI data, wetland models and inundation extent data, as well as the emission quantification method. Section 3 presents our results and discussion, including emission estimates from TROPOMI and their comparison with the process models, as well as an analysis of the differences between models and TROPOMI emission estimates using inundation extent and meteorological data. Our conclusions are given in Sect. 4.

\section{Data and methods}

\section{$2.1 \quad$ TROPOMI methane data}

TROPOMI is the single instrument onboard the Copernicus Sentinel-5 Precursor (S-5P) satellite, launched on 13 October 2017 in a sun-synchronous orbit at $824 \mathrm{~km}$ of altitude (Veefkind et al., 2012). It is a push-broom imaging spectrometer recording spectra along a $2600 \mathrm{~km}$ swath while orbiting the Earth every $100 \mathrm{~min}$, resulting in daily global coverage. Total column methane $\left(\mathrm{XCH}_{4}\right)$ is retrieved with nearly uniform sensitivity in the troposphere from its absorption band around $2.3 \mu \mathrm{m}$ using earthshine radiance measurements from the shortwave infrared (SWIR) channel of TROPOMI (Hu et al., 2016, 2018). TROPOMI $\mathrm{XCH}_{4}$ has a ground pixel size of $7 \times 7 \mathrm{~km}^{2}\left(7 \times 5.5 \mathrm{~km}^{2}\right.$ since August 2019) at nadir, with larger ground pixels towards the edges of its swath.

In this study, we use the operational two-band retrieval product of TROPOMI (Hasekamp et al., 2019). It uses $0.76 \mu \mathrm{m} \mathrm{O} \mathrm{O}_{2} \mathrm{~A}$ and $2.3 \mu \mathrm{m} \mathrm{CH}_{4}$ bands in the near-infrared (NIR) and SWIR spectra. $\mathrm{XCH}_{4}$ is retrieved using the fullphysics RemoTeC algorithm, which accounts for light path perturbations due to scattering by aerosol and cirrus cloud particles in the atmosphere (Butz et al., 2012; $\mathrm{Hu}$ et al., 2016). We only use high-quality $\mathrm{XCH}_{4}$ measurements retrieved under favorable cloud-free conditions. Also, $\mathrm{XCH}_{4}$ is filtered $(q a=1)$ for solar zenith angle $\left(<70^{\circ}\right)$, viewing zenith angle $\left(<60^{\circ}\right)$, smooth topography (1 SD surface elevation variability $<80 \mathrm{~m}$ within a $5 \mathrm{~km}$ radius) and low aerosol load (aerosol optical thickness $<0.3$ in the NIR band). Note that $\mathrm{Hu}$ et al. (2018) used 2 months of $\mathrm{XCH}_{4}$ data from the 
"scientific" retrieval product of the SRON Netherlands Institute for Space Research. Those measurements had relatively sparse temporal coverage over South Sudan because they were performed during the commissioning phase of TROPOMI when algorithm tests and calibrations were ongoing. The operational product used here provides more temporally homogenous coverage and a surface-albedo-dependent bias correction (Hasekamp et al., 2019).

\subsection{Process model data}

We compare TROPOMI emission estimates with two wetlands process models: Wetcharts (Bloom et al., 2017) and LPJ-wsl (Zhang et al., 2016). These models calculate monthly methane emissions on a global grid of $0.5^{\circ} \times 0.5^{\circ}$ resolution by simulating the microbial production and oxidation processes in the soil using temperature, inundation extent and heterotrophic respiration data. Wetcharts calculates wetland emissions using four inundation extent parameterizations, nine terrestrial biosphere models of heterotrophic respiration and three $\mathrm{CH}_{4}: \mathrm{C}$ temperature parameterizations $\left(q_{10}\right)$. Wetcharts version 1.0 provides two ensembles: $(1)$ an ensemble with 324 emission estimates for 2009-2010, called the full ensemble, and (2) an 18-member extended-in-time ensemble for 2001-2015, called the Wetcharts extended ensemble. In the Wetcharts full ensemble, the four inundation extent estimates are calculated based on two maximum wetland area estimates multiplied by two monthly varying scaling factors. The wetlands area estimates are taken from (1) the Global Lakes and Wetlands Database (GLWD; Lehner and Döll, 2004) and (2) the sum of all GLOBCOVER wetland and freshwater land types (Bontemps et al., 2011). The scaling factors are calculated from (1) precipitation data from ERA-Interim meteorological data and (2) inundation extent data from the Surface WAter Microwave Product Series (SWAMPS) multi-satellite surface water product (Schroeder et al., 2015). The 18-member Wetcharts extended ensemble provides emission estimates for only the two inundation extent estimates that are based on ERA-Interim and only one terrestrial biosphere model, CARDAMOM (Bloom et al., 2016).

The LPJ-wsl methane model is based on the processbased dynamic global vegetation model Lund-Potsdam-Jena (LPJ). It uses soil temperature, the soil moisture-dependent fraction of heterotrophic respiration $\left(R_{\mathrm{h}}\right)$ and inundation extent to calculate wetlands methane emissions. The inundation extent of LPJ-wsl is calculated by the TOPographybased hydrological model (TOPMODEL) driven by meteorology from ERA-Interim. TOPMODEL simulates hydrologic fluxes of water, including lateral transport such as infiltration-excess overland flow, infiltration, exfiltration, subsurface flow, evapotranspiration and channel routing through a watershed.

\subsection{Inundation extent data}

Earlier studies have indicated that water availability is particularly important in the tropics (temperature is less limiting here in contrast to high latitudes), and hence inundation extent is one of the main sources of uncertainty for tropical wetlands (Bloom et al., 2010; Ringeval et al., 2010). We analyze the inundation extent data used in process models: TOPMODEL (used in LPJ-wsl); GLWD and GLOBCOVER with ERA-Interim (used in the Wetcharts extended ensemble). We compare these inundation extent estimates against the remote-sensing-based high-resolution inundation extent data from Gumbricht et al. (2017), which maps wetlands and peatlands at $231 \mathrm{~m}$ spatial resolution by combining three biophysical indices related to wetland and peat formation: (1) long-term water supply exceeding atmospheric water demand, (2) annually or seasonally waterlogged soils, and (3) geomorphological position where water is supplied and retained. They use 2011 MODIS data to map the duration of wet and inundated soil conditions and the Shuttle Radar Topography Mission (SRTM) for topography. In addition, we use satellite-altimetry-based water height measurements from the Hydroweb database (Crétaux et al., 2011; Da Silva et al., 2010). The water height anomalies of the White Nile and Sobat rivers are used as a proxy for inundation extent variations in the Sudd and Machar wetlands, respectively. Fig. 1b shows the location of the river height measurement sites. We also analyze temperature and precipitation data from the European Centre for Medium-Range Weather Forecasts' ERA5 meteorological reanalysis (Hersbach and Dee, 2016).

\subsection{Emission quantification method}

The wetland distribution from Gumbricht et al. (2017) is shown in Fig. 1 for the region in South Sudan where a large TROPOMI $\mathrm{XCH}_{4}$ enhancement can be observed. This region, which includes Sudd, Machar and other smaller wetlands, is hereafter referred to as the South Sudan wetland region (SSWR). To calculate emissions, we first prepare seasonally averaged TROPOMI $\mathrm{XCH}_{4}$ maps on a grid of $0.1^{\circ} \times 0.1^{\circ}$ resolution. Only grid cells with at least five highquality TROPOMI measurements are used in the season average map. We apply the mass balance method of Buchwitz et al. (2017) to calculate emissions from December 2017 to November 2019. The emission $Q\left(\mathrm{Tg} \mathrm{yr}^{-1}\right)$ from the SSWR box in Fig. 1a for a given period is calculated using the following equation:

$Q=\Delta \mathrm{XCH}_{4} \times M \times M_{\exp } \times L \times V \times C$,

where $\triangle \mathrm{XCH}_{4}$ is the "source $\mathrm{XCH}_{4}$ enhancement", i.e., the mean $\mathrm{XCH}_{4}$ difference between the source and the surrounding background. $C$ is a dimensionless factor of 2.0 derived by Buchwitz et al. (2017) based on the concentration difference of air parcels before and after entering a source area. $M$ 


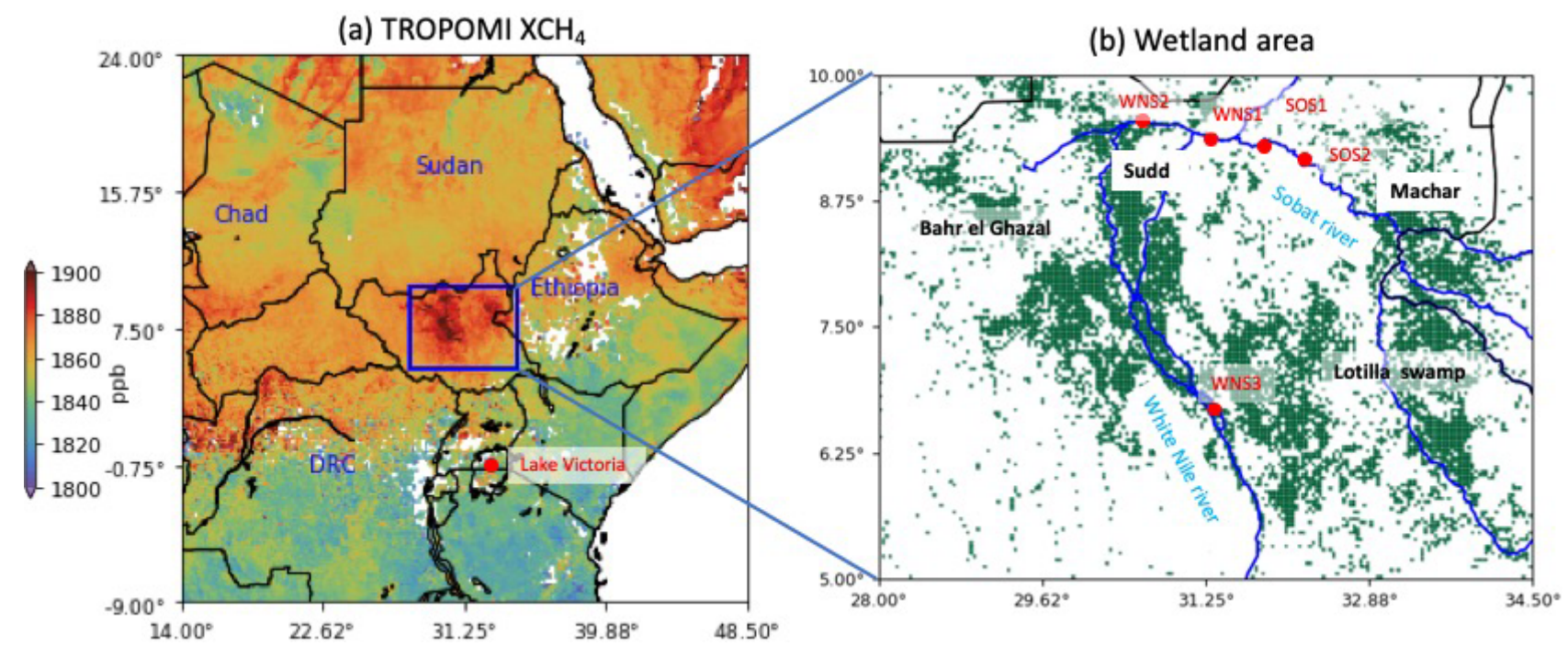

Figure 1. The TROPOMI XCH 4 enhancement over the South Sudan wetlands. (a) Average of 2 years (December 2017 to November 2019 ) of TROPOMI $\mathrm{XCH}_{4}$ at $0.1^{\circ} \times 0.1^{\circ}$ resolution. (b) Wetlands in South Sudan from Gumbricht et al. (2017) are shown in green, and the rivers in the region are shown in blue. The area within the blue rectangle $\left(5-10^{\circ} \mathrm{N}\right.$ and $\left.28-34.5^{\circ} \mathrm{E}\right)$ is referred to as the South Sudan wetlands region (SSWR). The red dots show the locations of satellite-altimetry-based river water height measurement sites.

$\left(5.345 \times 10^{-6} \mathrm{Tg} \mathrm{CH}_{4} \mathrm{~km}^{-2} \mathrm{ppb}^{-1}\right)$ is the atmospheric total column mixing ratio to mass conversion factor for a standard surface pressure of $1013.25 \mathrm{hPa}$, which is the standard atmospheric pressure. $M_{\text {exp }}$ is a dimensionless factor used to correct for the changes in column air mass with surface elevation, calculated as the ratio of surface pressure in the source and standard atmospheric pressure. $L$ is the "effective size" of the source region $(632 \mathrm{~km})$, calculated as the square root of its area $\left(4.0 \times 10^{5} \mathrm{~km}^{2}\right) . V\left(\mathrm{~km} \mathrm{yr}^{-1}\right)$ is the ventilation wind speed derived from the ERA5 meteorological reanalysis vertical wind speed profile. Surface elevation variations change the contribution of tropospheric to the total atmospheric column, which influences $\mathrm{XCH}_{4}$. TROPOMI $\mathrm{XCH}_{4}$ maps are corrected for this effect by adding the correction factor $7 \mathrm{ppb} \mathrm{km}^{-1}$ from Buchwitz et al. (2017) using the GMTED2010 elevation data shown in Fig. A1 (Danielson et al., 2011). We remove the large-scale latitudinal $\mathrm{XCH}_{4}$ gradient from the seasonal average TROPOMI $\mathrm{XCH}_{4}$ maps by subtracting a third-order polynomial fit from the background region, excluding the source region (see Fig. 2a).

Figure 3 shows the monthly average ERA5 wind speed at 10:00 UTC (TROPOMI overpass time) in the SSWR as a function of pressure within the local boundary layer during select months. To calculate $V$, the pressure-weighted average of these boundary layer wind speeds is calculated over SSWR using monthly average ERA5 boundary layer height data. We use average boundary layer winds instead of $10 \mathrm{~m}$ winds because they were found to better represent the ventilation wind speed in the source region (see Varon et al., 2018). For SSWR, the $10 \mathrm{~m}$ wind speed is on average $35 \%$ lower than the boundary layer wind speed, consistent with the diminishing influence of the surface friction with height.

The uncertainty of $Q$ is calculated as the sum in quadrature of uncertainties associated with $\Delta \mathrm{XCH}_{4}$ and $V$. The $\triangle \mathrm{XCH}_{4}$ uncertainty is estimated as the sum in quadrature of (1) $1 \mathrm{SD}$ of $\triangle \mathrm{XCH}_{4}$ estimates calculated by sequentially increasing the size of the background box from 1 to $10^{\circ}$ longitude and latitude in $1^{\circ}$ intervals and (2) the $\mathrm{XCH}_{4}$ uncertainty of a single $0.1^{\circ} \times 0.1^{\circ}$ grid cell on the average map (22 ppb), taken as $1 \mathrm{SD} \mathrm{XCH}_{4}$ of all the grid cells in Fig. 1a. Note that this approach overestimates the $\mathrm{XCH}_{4}$ uncertainty of the grid cells as $\mathrm{XCH}_{4}$ variations within the grid are also caused by emissions and surface elevation variations in addition to measurement errors. The uncertainty of $V$ is estimated from the variation in wind speed during a consecutive $4 \mathrm{~h}$ period (09:00, 10:00, 11:00, 12:00 UTC) centered around the TROPOMI overpass time. Note that we use the mass balance method equation from Buchwitz et al. (2017), but not their empirical equation, to estimate the uncertainty of $Q$. They derive that equation using a fixed wind speed of $1.1 \mathrm{~m} \mathrm{~s}^{-1}$ globally, which would give a larger uncertainty in comparison to our approach of using location- and time-specific wind information: ERA5 average $V$ is $2.5 \pm 0.42 \mathrm{~m} \mathrm{~s}^{-1}$ in SSWR during 2018-2019.

\section{Results}

\section{1 $\mathrm{XCH}_{4}$ enhancements}

We first assess the $\mathrm{XCH}_{4}$ enhancements over South Sudan from the 2-year average map of TROPOMI $\mathrm{XCH}_{4}$ shown 
TROPOMI XCH

(a) DJF-2018

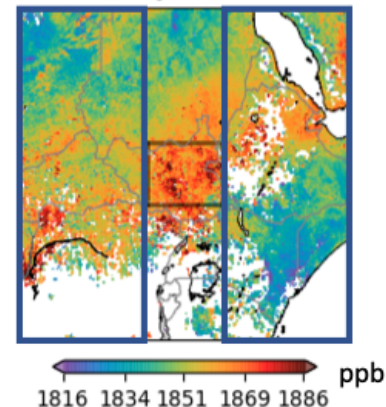

(e) DJF-2019

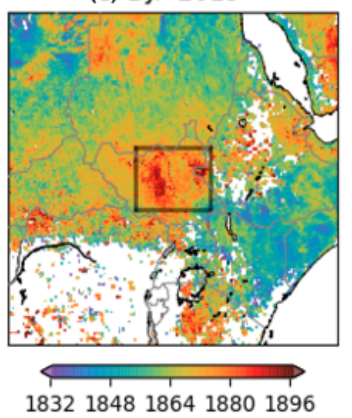

(b) MAM-2018

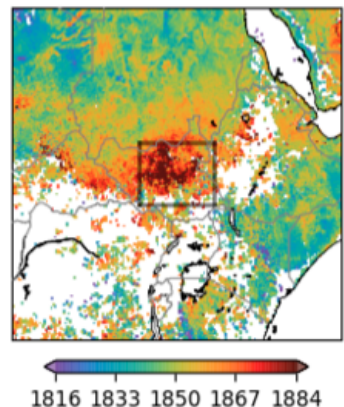

(f) MAM-2019

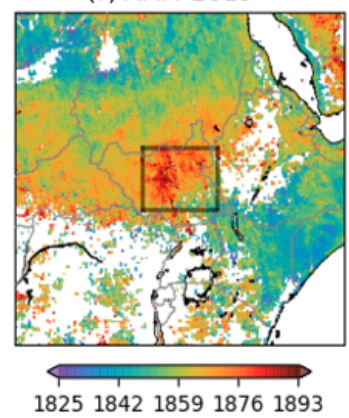

(c) JJA-2018

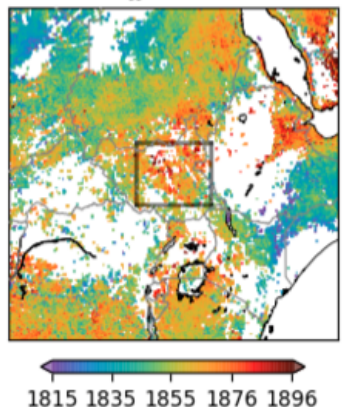

(i) JJA-2019

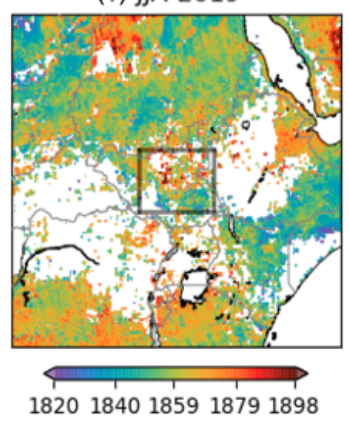

(d) SON-2018

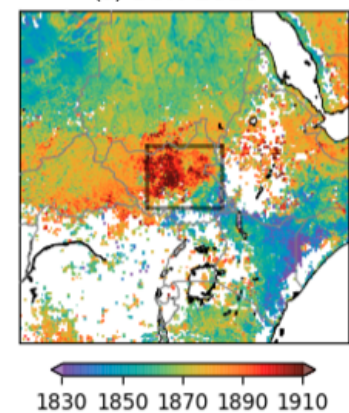

(j) SON-2019

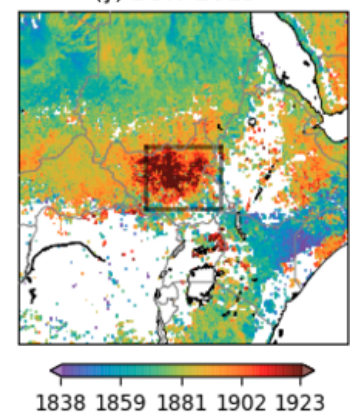

Figure 2. Seasonally averaged TROPOMI $\mathrm{XCH}_{4}(\mathrm{ppb})$ at $0.1^{\circ} \times 0.1^{\circ}$ resolution. The black rectangle at the center of each panel shows the SSWR source region. The area outside it is used as the background region. $\mathrm{XCH}_{4}$ is corrected for large-scale latitudinal variations by subtracting a third-order polynomial fit using the region shown by blue rectangles in panel (a). The region excludes the longitudes of the source region. Note that DJF includes December of the previous year.

in Fig. 1a in relation to the SSWR wetland distribution in Fig. 1b. Similar to previous remote sensing studies (Frankenberg et al., 2011; Lunt et al., 2019; Hu et al., 2018), we observe a large $\mathrm{XCH}_{4}$ enhancement over the Sudd wetlands. In addition, the TROPOMI data also resolve another distinct enhancement over the Machar and Lotilla wetlands in eastern South Sudan, indicating large emissions from these wetlands too. The second enhancement was also observed by $\mathrm{Hu}$ et al. (2018) using 2 months of TROPOMI $\mathrm{XCH}_{4}$.

The Sudd wetlands are flooded by the main White Nile tributary originating from Lake Victoria, whereas the wetlands in southeast Sudan are along smaller rivers like the Kangen and Sobat, originating from the Ethiopian mountains. Lunt et al. (2019) attributed their GOSAT inversion emission estimates only to Sudd and evaluated the emissions using auxiliary data for Sudd. However, as the wetlands in the east are flooded by a different set of rivers and have a substantial contribution to the overall $\mathrm{XCH}_{4}$ enhancement, they also need to be considered when studying the mechanisms driving the large emissions in this region.

The $\mathrm{XCH}_{4}$ enhancement for SSWR in the 2-year average is $18.8 \pm 2.8 \mathrm{ppb}$, which is more than 3 times the enhancement over the Permian basin in the USA as reported by Zhang et al. (2020). It is very unlikely that the SSWR enhancement is an artifact of the known aerosol or surface albedo biases in the TROPOMI $\mathrm{XCH}_{4}$ data. We elaborate further on this in Appendix A. Figure 2 shows seasonally average $\mathrm{XCH}_{4}$ maps over SSWR, and Table 1 quantifies the seasonal $\mathrm{XCH}_{4}$ enhancement and areal coverage of the TROPOMI data. TROPOMI has good coverage in SSWR, ranging from $40 \%$ in JJA to $>90 \%$ in DJF. It is higher than $70 \%$ in all seasons except JJA, likely due to persistent cloud cover during the wet season. The lowest enhancements are observed in JJA in both $2018(10.5 \pm 4.1 \mathrm{ppb})$ and 2019 $(2.6 \pm 3.7 \mathrm{ppb})$. It is unlikely that these low enhancements are artifacts of the low coverage as there are still sufficient TROPOMI data (>40\%) and measurements are not systematically missing over the large emissions areas of SSWR, which are the Sudd and Machar wetlands. SON 2019 has the largest enhancement of $29.3 \pm 4.0 \mathrm{ppb}$, likely due to low wind speeds.

\subsection{Emissions quantification}

We use the mass balance method of Buchwitz et al. (2017) to estimate emissions from SSWR for each season (see Table 1). Emissions during most seasons are close to $10 \mathrm{Tg} \mathrm{yr}^{-1}$, except for the low emissions in JJA. We find very low emissions in JJA $2019\left(1.4 \pm 2.1 \mathrm{Tg} \mathrm{yr}^{-1}\right)$, but 


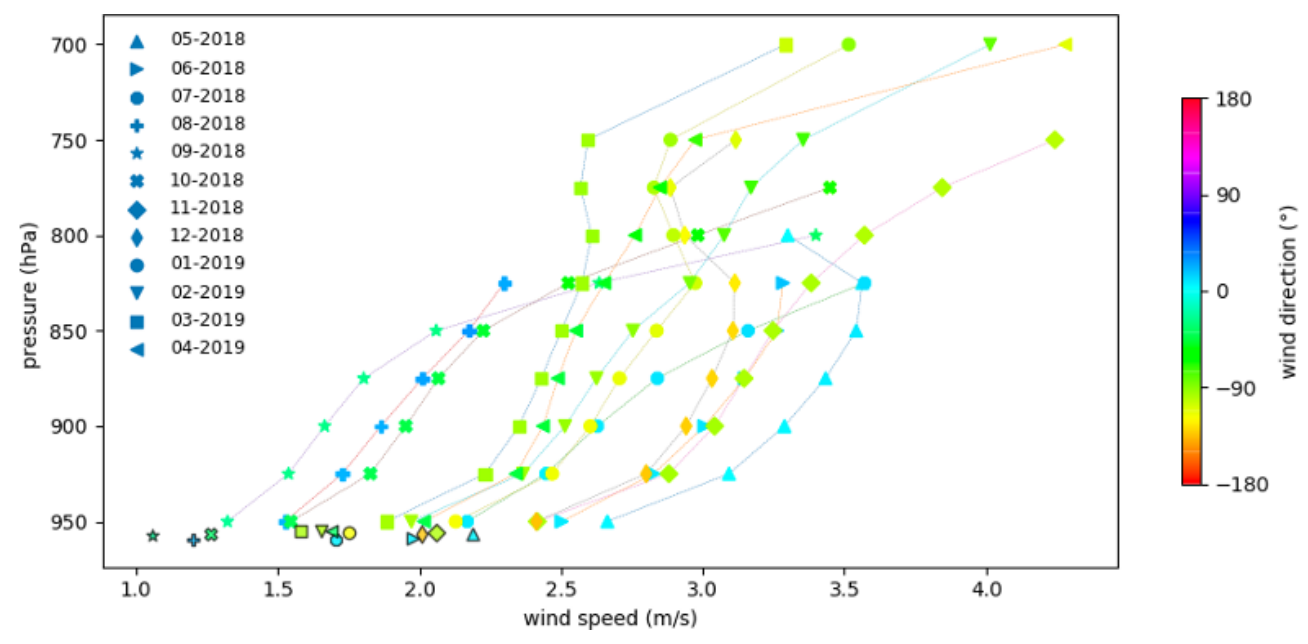

Figure 3. Monthly average boundary layer ERA5 winds in SSWR. Wind speeds ( $x$ axis) and directions (color of the markers) at 10:00 UTC, which is the closest hour to the local TROPOMI overpass time, are shown at different pressure levels of the model. The markers with dark edges represent $10 \mathrm{~m}$ height winds.

Table 1. SSWR $\mathrm{XCH}_{4}$ enhancement and emission estimates. The enhancements $\left(\mathrm{XCH}_{4}\right)$ are the $\mathrm{XCH}_{4}$ difference between SSWR and the background after correcting $\mathrm{XCH}_{4}$ for latitudinal variations. Data coverage is defined here as the fraction of $0.1^{\circ} \times 0.1^{\circ}$ grid cells in SSWR with at least five high-quality TROPOMI measurement in a quarter. Wind speed is the average boundary layer wind from ERA5. Emission estimates are calculated using Eq. (1); \pm represents $1 \sigma$ uncertainty.

\begin{tabular}{lrrrr}
\hline Season & $\begin{array}{r}\text { Data } \\
\text { coverage } \\
(\%)\end{array}$ & $\begin{array}{r}\text { Wind } \\
\text { speed } \\
\left(\mathrm{m} \mathrm{s}^{-1}\right)\end{array}$ & $\begin{array}{r}\mathrm{XCH}_{4} \\
\text { enhancement } \\
(\mathrm{ppb})\end{array}$ & $\begin{array}{r}\text { Emissions } \\
\left(\mathrm{Tg} \mathrm{yr}^{-1}\right)\end{array}$ \\
\hline DJF-2018 & 91 & $3.5 \pm 0.9$ & $16.5 \pm 4.3$ & $11.5 \pm 4.2$ \\
MAM-2018 & 74 & $2.1 \pm 1.2$ & $20.2 \pm 4.1$ & $8.5 \pm 5.1$ \\
JJA-2018 & 44 & $2.7 \pm 0.3$ & $10.5 \pm 4.1$ & $5.7 \pm 2.3$ \\
SON-2018 & 83 & $2.7 \pm 0.4$ & $18.7 \pm 4.3$ & $10.1 \pm 2.8$ \\
DJF-2019 & 98 & $3.2 \pm 0.9$ & $13.4 \pm 2.7$ & $8.6 \pm 3.0$ \\
MAM-2019 & 92 & $3.1 \pm 0.8$ & $13.6 \pm 3.6$ & $8.4 \pm 3.1$ \\
JJA-2019 & 43 & $2.8 \pm 0.3$ & $2.6 \pm 3.7$ & $1.4 \pm 2.1$ \\
SON-2019 & 83 & $1.9 \pm 0.2$ & $29.3 \pm 4.0$ & $11.2 \pm 1.9$ \\
\hline
\end{tabular}

they accommodate the season's anthropogenic emissions of about $0.48 \mathrm{Tg} \mathrm{yr}^{-1}$ (sum of 2012 EDGAR emissions and 2016 oil and gas emissions from Scarpelli et al., 2020) and GFED biomass burning emissions $\left(0.003 \mathrm{Tg} \mathrm{yr}^{-1}\right)$. Direct application of the mass balance method to the 2-year average $\mathrm{XCH}_{4}$ map shown in Fig. 1a yields annual emissions of $10 \pm 1.7 \mathrm{Tg} \mathrm{yr}^{-1}$. However, this is likely an overestimate as the 2-year average temporally under-samples the low emissions of JJA seasons due to low coverage during these seasons. Therefore, to ensure uniform temporal sampling of all seasons, we calculate annual SSWR emissions by averaging the seasonal emission estimates, resulting in $8.2 \pm 3.2 \mathrm{Tg}^{-1}$. Moreover, this approach is likely less sen- sitive to error due to the mean-of-products vs. the productof-means effect. A caveat of the mass balance method is that it ignores two factors: (1) the influence of emissions in the background region and (2) the contribution of emissions in the source region to the background average $\mathrm{XCH}_{4}$. Both factors increase the background $\mathrm{XCH}_{4}$ and ignoring them results in an underestimation of the emission estimate. However, this underestimation is large when the ratio of the area of the background region to the source region is small, and as we apply the method using a large background, we do not expect a significant impact on our emission estimates.

Lunt et al. (2019) report methane emissions for all sources (including wetlands, biomass burning, anthropogenic, wild animals) from the Sudd wetlands using multiyear GOSAT inversions. Their emission estimate of $5.2-6.9 \mathrm{Tg} \mathrm{yr}^{-1}$ for 2016 is within the uncertainty bounds of our SSWR total emission estimate of $8.0 \pm 3.2 \mathrm{Tg} \mathrm{yr}^{-1}$ for $2018-2019$. Note that some difference in the emission estimates can be explained by the difference in the definition of the source region between the two studies as their region extends more north and less east than ours. TROPOMI shows a large $\mathrm{XCH}_{4}$ enhancement over the Lotilla and Machar wetlands in the east SSWR, indicating large emissions from these wetlands. As the source region in Lunt et al. (2019) only partially covers these wetlands, our emission estimates are expected to be higher.

To calculate wetlands emissions from SSWR, we account for other methane emissions in the region using bottom-up data. According to the EDGAR (version 4.3.2; JanssensMaenhout et al., 2017) inventory for 2012, the total anthropogenic emissions from SSWR were $0.43 \mathrm{Tg} \mathrm{yr}^{-1}$, with enteric fermentation $\left(0.36 \mathrm{Tg} \mathrm{yr}^{-1}\right)$ being the largest anthropogenic category. The region has small emissions from wastewater management $\left(0.03 \mathrm{Tg} \mathrm{yr}^{-1}\right)$, energy for build- 
ings $\left(0.01 \mathrm{Tg} \mathrm{yr}^{-1}\right)$ and manure management $\left(0.01 \mathrm{Tg} \mathrm{yr}^{-1}\right)$. EDGAR does not report any significant emissions from the fossil fuel exploitation sector in the region. Recently, Scarpelli et al. (2020) presented a new inventory for the oil and gas sector in which UNFCCC reported that national emissions are spatially allocated to the fossil fuel infrastructure. They report $0.05 \mathrm{Tg} \mathrm{yr}^{-1}$ of emissions from SSWR in 2016. Biomass burning is the largest natural methane source after wetlands in SSWR, with average emissions of $0.20 \mathrm{Tg} \mathrm{yr}^{-1}$ in 2018-2019 according to GFED4s $\left(0.23 \mathrm{Tg} \mathrm{yr}^{-1}\right.$ in $2018,0.16 \mathrm{Tg} \mathrm{yr}^{-1}$ in 2019 ; van der Werf et al., 2017). Another significant natural source is emissions from termites $\left(0.16 \mathrm{Tg} \mathrm{yr}^{-1}\right.$; Sanderson, 1996). We subtract the total of these non-wetlands emissions to calculate wetland emissions of $7.4 \pm 3.2 \mathrm{Tg} \mathrm{yr}^{-1}$ from SSWR in 20182019. This estimate is an order of magnitude larger than the $0.5 \mathrm{Tg} \mathrm{yr}^{-1}$ wetlands emissions from the prominent Pantanal wetlands of South America in 2010-2018, which are estimated using GOSAT inversions by Tunnicliffe et al. (2020).

Our SSWR wetlands emission estimate of $7.4 \pm 3.2 \mathrm{Tg} \mathrm{yr}^{-1}$ can be an overestimate if the emissions from the abovementioned non-wetlands sectors are underestimated in the inventories. However, this is unlikely as it would require a very large underestimation in the inventories for the 2 years studied here. For example, for the oil and gas sector, the annual emissions $\left(0.05 \mathrm{Tg} \mathrm{yr}^{-1}\right)$ would need to be underestimated by 2 orders of magnitude to have a significant error impact on the wetland emission estimates. Moreover, the strong seasonality shown by the TROPOMI emission estimates is not expected in oil and gas emissions. The SSWR biomass burning emissions are higher than other sectors, but a large underestimation in annual emissions by GFED is unlikely as it uses remote-sensing-based fire activity and vegetation productivity data. There are a large number of wild animals in the SSWR, which in total emit $0.03 \mathrm{Tg} \mathrm{yr}^{-1}$ as per Crutzen et al. (1986). Livestock is the largest anthropogenic methane source in the SSWR: $0.36 \mathrm{Tg} \mathrm{yr}^{-1}$ in 2012 as per EDGAR v4.3.2 and 0.37 $\mathrm{Tg} \mathrm{yr}^{-1}$ in 2015 as per EDGAR version 5 (Crippa et al., 2020). South Sudan has a large population of livestock: 7.5 million dairy cattle, 4.6 million non-dairy cattle, 13.5 million goats and 16.3 million sheep in 2018, which causes $0.63 \mathrm{Tg} \mathrm{yr}^{-1}$ of methane emissions (FAOSTATS, 2020). This amount is twice what we use to calculate the wetlands emissions for SSWR. Manure management emissions in SSWR $\left(0.01 \mathrm{Tg} \mathrm{yr}^{-1}\right.$ as per EDGAR v4.3.2) are small even though there is a large cattle population in South Sudan due to lack of effective management practices. This is reflected in the small emission factors used for manure management for the country by EDGAR; for example, the dairy cattle emission factors are $1 \mathrm{~kg} \mathrm{CH}_{4}$ per head for South Sudan vs. $48 \mathrm{~kg} \mathrm{CH}_{4}$ per head for the USA. As per FAOSTATS (2020), the total emissions from manure management of dairy and non-dairy cattle, asses, chickens, sheep and goats from the whole of South Sudan are $0.02 \mathrm{Tg} \mathrm{yr}^{-1}$. In the extreme case that all these South Sudan emissions are located in SSWR, it would slightly reduce our wetland emission estimate but still be well within its uncertainty margin.

\subsection{Comparison to wetland process models}

\subsubsection{Annual means}

SSWR integrated mean methane emission estimates from the process models are nearly an order of magnitude lower than those from TROPOMI (Table 2). For example, the multiannual mean emissions from LPJ-wsl for 1980-2016 are $1.1 \mathrm{Tg} \mathrm{yr}^{-1}$ (ranging from $0.5 \mathrm{Tg} \mathrm{yr}^{-1}$ in 1990 to $1.5 \mathrm{Tg} \mathrm{yr}^{-1}$ in 1998). The multi-annual mean individual ensemble estimates from the Wetcharts extended ensemble range from $0.4 \mathrm{Tg} \mathrm{yr}^{-1}$ (uses GLWD) to $1.8 \mathrm{Tg} \mathrm{yr}^{-1}$ (uses GLOBCOVER). The smallest and largest annual emission estimates from these ensemble members are $0.29 \mathrm{Tg} \mathrm{yr}^{-1}$ in 2009 and $2.21 \mathrm{Tg} \mathrm{yr}^{-1}$ in 2013. The Wetcharts full ensemble, with 324 estimates for 2009-2010, has a mean of $0.9 \mathrm{Tg} \mathrm{yr}^{-1}$,

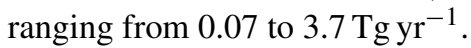

Table 2 also presents the maximum SSWR inundation extent (i.e., sum of seasonal and permanent wetland areas) used by the process models. They range from 25000 to $69000 \mathrm{~km}^{2}$ across the models and are up to 4 times lower than the observation-based maximum inundation extent estimates of $99000 \mathrm{~km}^{2}$ by Gumbricht et al. (2017). Huges and Huges (1992) give the permanent wetland area of the different wetlands in SSWR (Table A1 in the Appendix). The sum of these areas is $36000 \mathrm{~km}^{2}$, significantly larger than the permanent inundation extent (i.e., minimum inundation extent) used in the models (Wetcharts extended ensemble: $1000 \mathrm{~km}^{2}$; LPJ-wsl: $14000 \mathrm{~km}^{2}$; SWAMPS: $16000 \mathrm{~km}^{2}$ ). Rebelo et al. (2012) used remote sensing data to characterize the inundation extent of the Sudd wetlands over a 12-month period, yielding a total wetlands area of $50000 \mathrm{~km}^{2}\left(41000 \mathrm{~km}^{2}\right.$ seasonally inundated and $9000 \mathrm{~km}^{2}$ permanently inundated). According to Huges and Huges (1992), other wetlands in the SSWR have a total permanent wetlands area of $>20500 \mathrm{~km}^{2}$, meaning that Sudd accounts for only about a third of the SSWR's total wetland area. As other wetlands in SSWR are also along rivers like the Sobat, their inundation extent likely has a large seasonality, and assuming that the relative seasonal amplitude of the inundation extent of these other wetlands is similar to that of Sudd would give a total (seasonal + permanent) flooded area of $134000 \mathrm{~km}^{2}$. Adding the Sudd inundation extent yields a total SSWR inundation extent of $164000 \mathrm{~km}^{2}$, which is larger than the total estimate of $99000 \mathrm{~km}^{2}$ from Gumbricht et al. (2017). Overall, we find substantial evidence of underestimations of SSWR inundation extent in the process models, which may explain their emission underestimations as they assume that inundation extent is a strong control of the emissions.

We now look at variations in annual mean inundation extent to find a possible cause of the high emissions in 2018 
Table 2. Annual emission and maximum inundation extent estimates for SSWR. The values in parentheses show 1 SD spread over the given periods. The dashed values give the range of Wetcharts ensemble estimates.

\begin{tabular}{lrrr}
\hline & Period & $\begin{array}{r}\text { Maximum } \\
\text { inundation } \\
\text { extent } \\
\left(10^{3} \mathrm{~km}^{2}\right)\end{array}$ & $\begin{array}{r}\text { Emissions } \\
\left(\mathrm{Tg} \mathrm{yr}^{-1}\right)\end{array}$ \\
\hline Wetcharts extended ensemble, GLWD & $2001-2015$ & $32(7)$ & $0.4(0.1)-1.0(0.2)$ \\
Wetcharts extended ensemble, GLOBCOVER & $2001-2015$ & $69(10)$ & $0.70(0.1)-1.8(0.2)$ \\
Wetcharts full ensemble & 2010 & $30-66$ & $0.07-3.7$ \\
LPJ-wsl, TOPMODEL & $1980-2016$ & $57(9)$ & $1.1(0.25)$ \\
SWAMPS & $2001-2019$ & $25(5)$ & - \\
Gumbricht et al. (2017) & 2011 & 99 & - \\
TROPOMI & $2018-2019$ & - & $7.4 \pm 3.2$ \\
\hline
\end{tabular}

2019. Lunt et al. (2019) attribute the emission increase in South Sudan between 2010 and 2016 to an inundation extent increase in the Sudd owing to increased water inflow from the White Nile River found in satellite-altimetry-based river water height measurements. To investigate this for the period 2018-2019, we look at trends in water height (see Fig. 4) of Lake Victoria as well as the White Nile and Sobat rivers. Similar to Lunt et al. (2019), we observe a rapid water height increase during 2011-2014. After this period, water levels stabilize and slightly decrease but remain significantly higher than in 2009-2010. The year 2019 shows the highest water level for the Sobat River due to a renewed positive trend from 2017 onward. This suggests that the total SSWR inundation extent was significantly higher in 2018-2019 than the pre2011 levels. In contrast, the inundation extent data used in the process models, shown in Fig. 4a, have negative trends, which means that the process models do not account for the emission increase during 2010-2016 due to increasing inundation extent, as suggested by Lunt et al. (2019).

Inundation extent estimates from the remote-sensingbased SWAMPS also do not show the increase and underestimate annual means. Schroeder et al. (2015) have recommended not using SWAMPS absolute inundation extent as the microwave sensors used in SWAMPS have limited capability to detect water underneath the soil surface or beneath closed forest canopies. This effect can also impact temporal changes, in addition to the absolute inundation extent, as such flooding beneath forest canopies would also not be observed. It is unclear why TOPMODEL, which accounts for lateral water transport processes, does not capture the trend in river outflow. These are interesting topics for follow-on investigations.

\subsubsection{Seasonal cycle}

Next, we assess the seasonal cycle of the TROPOMI-derived emission estimates. Figure 5a shows the seasonal cycles in 2018 and 2019. The largest emissions are in DJF in 2018, while DJF, MAM and SON have large emissions of similar magnitude in 2019. In both 2018 and 2019, TROPOMI emissions are lowest in JJA; in contrast, the process models estimate the lowest emissions in DJF (Fig. 5c). We investigate this mismatch by looking at the seasonal cycle of inundation extent in the models. The model emissions have a strong correlation with the inundation extent they use (Wetcharts $R=$ 0.91 and LPJ-wsl $R=0.94$, where $R$ is correlation coefficient), indicating that the seasonality of emissions is driven by inundation extent. In fact, the differences in inundation extent seasonality between LPJ-wsl and Wetcharts are consistent with the emissions differences; for example, both inundation extent and emissions in LPJ-wsl are lower than in Wetcharts during MAM.

The seasonality of the altimetry-based river water height measurements, shown in Fig. 5d, is highest in SON and is very different from the Wetcharts inundation extent (highest in JJA). This can partially explain the difference in the seasonal cycles of Wetcharts and TROPOMI emissions. The seasonal cycle of Wetcharts inundation extent is strongly correlated with local precipitation (Fig. 5b), as the intra-annual inundation extent variation is calculated using precipitation. However, this method would not accurately account for inundation extent variation due to lateral water fluxes and evapotranspiration. Surface runoff is especially important for riverfed wetlands like Sudd, whose inundation extent is controlled by water inflow from the White Nile because the evapotranspiration rate exceeds rainfall in the region (Lunt et al., 2019; Sutcliffe and Brown, 2018). LPJ-wsl inundation extent seasonality shows better agreement with the river height data as it is calculated using TOPMODEL, which accounts for lateral fluxes and evapotranspiration. However, LPJ-wsl emissions still show large differences with the seasonal cycle of TROPOMI emissions. Previous remote sensing studies for the Sudd wetlands have found the largest inundation extent during September-January in 2007-2008 (Rebelo et al., 2012) and during December-January in 19911992 (Travaglia et al., 1995), in better agreement with river height measurements than the process models. Overall, the inundation extent seasonality of models appears to be signif- 
(a) Inundation extent
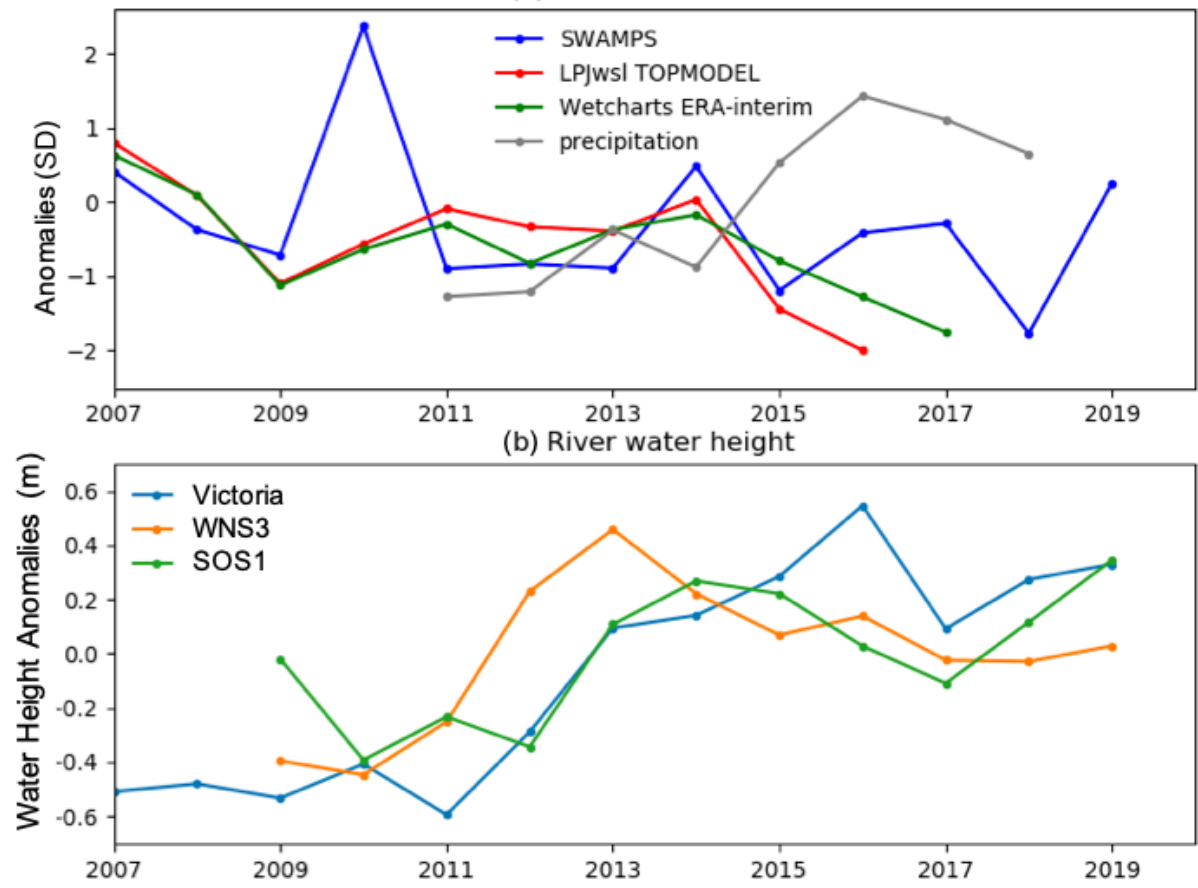

Figure 4. SSWR inundation extent estimates. (a) Annual anomalies of inundation extent estimates from SWAMPS, TOPMODEL and Wetcharts (ERA-Interim) used in process models, as well as ERA5 precipitation, expressed in units of the standard deviation of the respective annualized time series. (b) Water height anomalies for the altimetry sites in Lake Victoria as well as the White Nile (WNS3) and Sobat (SOS1) rivers from the Hydroweb database. Locations of these altimetry sites are given in Fig. 1. Here we only use the altimetry sites which have sufficiently long temporal coverage that includes 2018-2019.

icantly off, which can explain part of the mismatch between TROPOMI and model emissions. In both 2018 and 2019, TROPOMI emission estimates are the lowest during JJA, while river height measurements are the lowest in MAM. A similar seasonal cycle mismatch in the GOSAT emission estimates and inundation extent, derived using MODIS land surface temperature (LST) as a proxy, is shown in Lunt et al. (2019). Furthermore, they find the highest emissions trend during SON, which had the smallest trend in inundation, but no trend in emissions during MAM, which has the highest inundation extent trend (i.e., strongest negative LST trend).

An explanation for the difference in seasonal phasing can be a higher temperature dependence of emissions than suggested by the models as temperatures are lowest during JJA. We evaluate this hypothesis using the Wetcharts full ensemble, which provides a total of 324 emission estimates for three temperature dependences $q_{10}(1,2,3$; see Bloom et al., 2017). Figure 6 compares the average seasonal cycle of TROPOMI emissions with Wetcharts emissions using different $q_{10}$ values (see also Table 3 ). Wetcharts emissions with $q_{10}=1$ have the poorest agreement with the seasonal cycle of TROPOMI $(R=-0.62)$. Interestingly, these emissions also have the lowest annual means $\left(0.5 \mathrm{Tg} \mathrm{yr}^{-1}\right)$. Conversely, Wetcharts emissions with $q_{10}=3$ have the best correlation with TROPOMI $(R=-0.28)$ and have the largest annual mean $\left(1.0 \mathrm{Tg} \mathrm{yr}^{-1}\right)$. In fact, the member estimate - out of the 324-member full ensemble - with the largest annual emissions of $3.7 \mathrm{Tg} \mathrm{yr}^{-1}$ has the best correlation with TROPOMI $(R=0.00)$. As expected, this member uses $q_{10}=3$. The agreement of TROPOMI with the larger $q_{10}$ model estimates, in terms of both annual mean and seasonal cycle, suggests that wetland emissions from SSWR have a large temperature dependence. In their study of wetlands in the Amazon Basin, Tunnicliffe et al. (2020) pointed to temperature as a more important control on methane emissions than inundation extent. They find a simultaneous, spatially correlated emission and temperature increase in the western Brazilian Amazon during the El Niño of 2015, with an unchanged inundation extent. Moreover, Wilson et al. (2016) found a negligible impact on wetlands emissions in the Amazon Basin despite the large difference in precipitation between 2010 and 2011, which impacted the inundation extent significantly. Note that it is also possible that the higher $q_{10}$ values we find for SSWR emissions are simply compensating for errors due to a misrepresentation of inundation extent or other factors covarying with temperature.

Figure 7 shows the emission anomaly time series from TROPOMI along with temperature and inundation extent, which we assume to be proportional to river height. A small lag between the river height and inundation extent is ex- 
(a) TROPOMI emissions

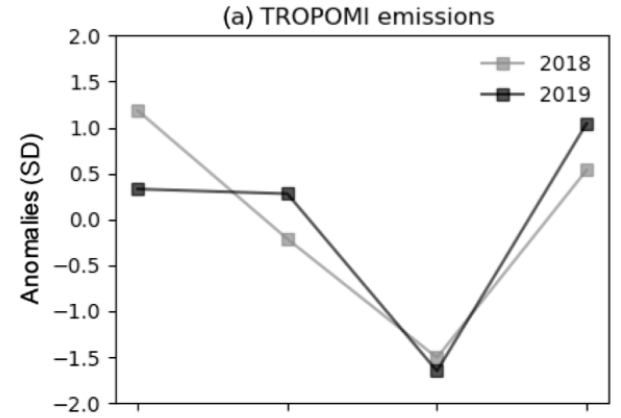

(c) Wetland models

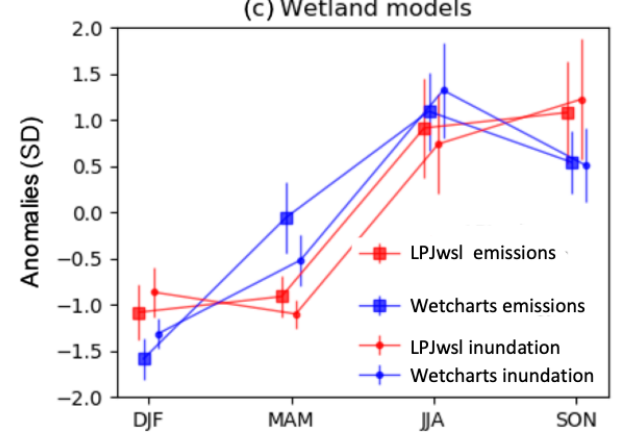

(b) ERA5

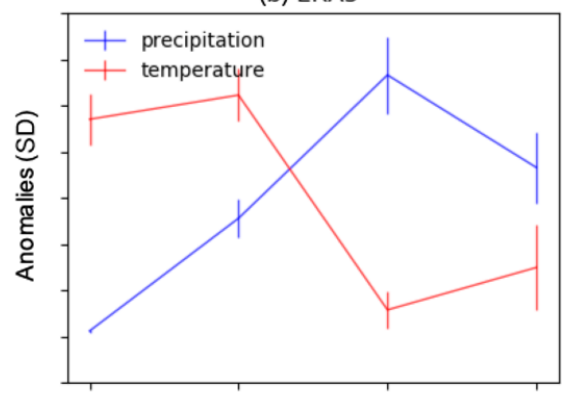

(d) River height

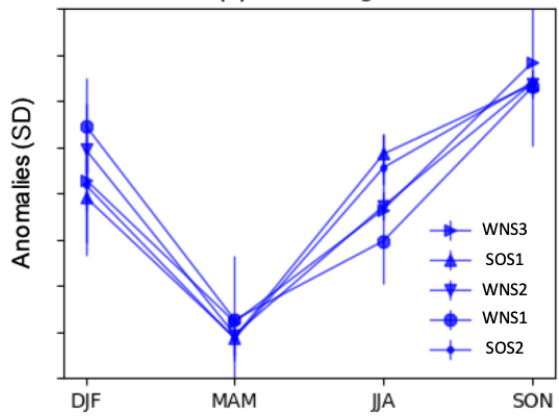

Figure 5. Mean seasonal cycles expressed in units of the standard deviation of the respective time series. (a) Emission estimates from TROPOMI; (b) precipitation and temperature from ERA5 (2010-2019); (c) emissions and inundation extent from the process models LPJwsl and Wetcharts extended ensemble; (d) river water height measurements at the altimetry sites given in Fig. $1 \mathrm{~b}$. The vertical bars represent 1 SD spread over different years.

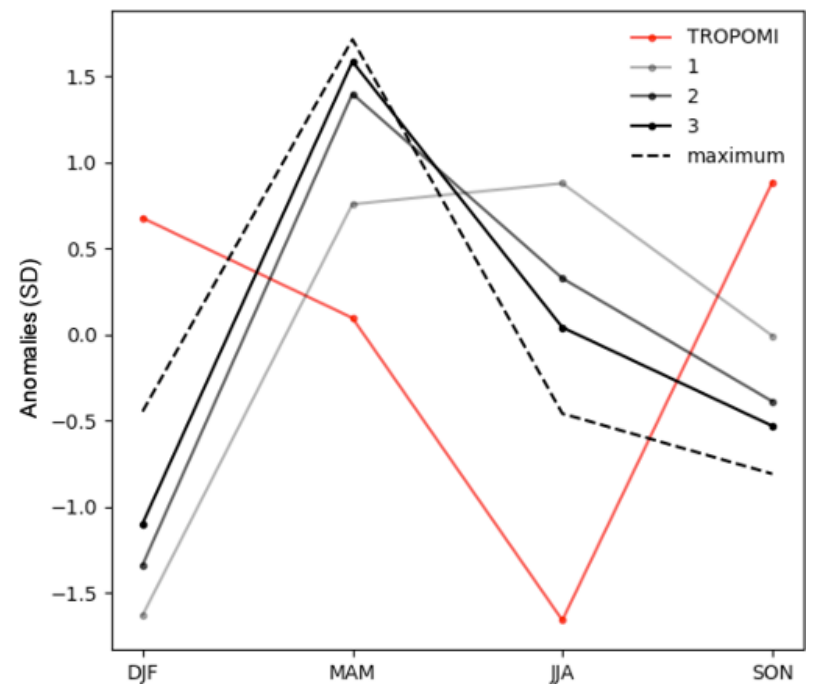

Figure 6. Seasonal cycle of SSWR emissions. Methane emissions from the Wetcharts full ensemble for 2010 (December 2009November 2010) and TROPOMI are shown. The solid lines show the average of an emission estimate ensemble for a temperature dependency $\left(q_{10}\right)$. The dashed line shows the seasonal cycle of the Wetcharts estimate that has the largest annual emissions. All values are shown in units of standard deviation.
Table 3. Annual emission estimates from the Wetcharts full ensemble (2010) for different temperature dependencies and the correlation coefficient $(R)$ of their respective average seasonal cycle with TROPOMI emissions.

\begin{tabular}{lrr}
\hline $\begin{array}{l}\text { Temperature } \\
\text { dependence } \\
\left(q_{10}\right)\end{array}$ & $\begin{array}{c}\text { Emissions } \\
\left(\mathrm{Tg} \mathrm{yr}^{-1}\right)\end{array}$ & $\begin{array}{r}R \\
(\text { with TROPOMI) }\end{array}$ \\
\hline 1 & 0.5 & -0.62 \\
2 & 0.8 & -0.41 \\
3 & 1.0 & -0.28 \\
Maximum* & 3.7 & 0.00 \\
\hline * The maximum annual emission estimate in the 324-member \\
ensemble of the Wetcharts full ensemble. Its $q_{10}$ is 3.
\end{tabular}

pected, but we expect it to be negligible in comparison to a full season. We observe that the emissions show a strong correlation with temperature $(R=0.49)$ but a poorer correlation with inundation extent $(R=0.24)$. The emissions peak a full season later than inundation extent, and accounting for this seasonal lag improves the correlation significantly $(R=0.80)$. An explanation for this can be the higher temperature dependence of emissions discussed earlier. Another explanation could be the "activation" time of methanogenesis, as after flooding it takes time for anoxic conditions to develop and alternative electron acceptors to be depleted. Jerman et 
(a)

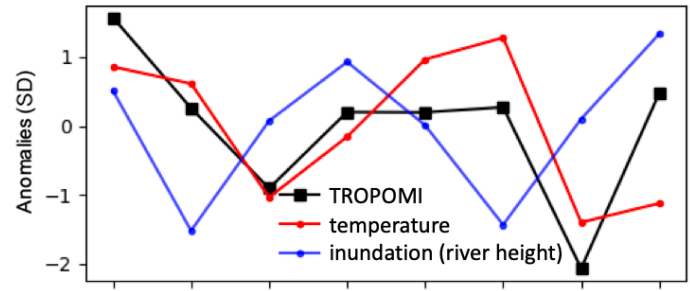

(b)

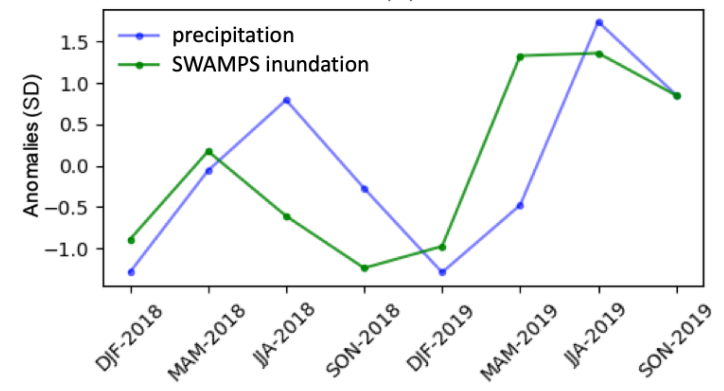

Figure 7. Seasonal anomalies in SSWR. (a) TROPOMI emissions estimates, ERA5 temperature and inundation extent from river height measurements are shown. (b) Local precipitation and SWAMPS inundation extent data are shown. All values are expressed in units of standard deviation. The correlation coefficients $(R)$ of TROPOMI emissions with temperature, river height, SWAMPS and precipitation are 0.49 and $0.24,-0.33$ and -0.67 , respectively.

al. (2009) documented evidence that methane emissions from water-saturated soil slurries remained very low for a long time: methane production started after a lag of $84 \mathrm{~d}$ at $15^{\circ} \mathrm{C}$ and a minimum of $7 \mathrm{~d}$ at $37^{\circ} \mathrm{C}$, the optimum temperature for methanogenesis. They found that the lag was inversely related to iron reduction, which is expected as iron reduction outcompeted methanogenesis. Similarly, Itoh et al. (2011) investigated methane emissions from rice paddy fields and found a time lag of a few weeks between the onset of inundation and peak emissions.

Process models assume that wetland emissions are instantaneously regulated by inundation extent, and they do not account for the time lag as information on the availability of alternate electron accepters is generally not available. This results in an incorrect temporal allocation of the wetland emissions. Furthermore, some models assume that inundation extent is instantaneously regulated by precipitation. In river floodplains like Sudd, inundation extent is mostly controlled by river inflow and not the local precipitation, as the evapotranspiration rates exceed rainfall in the region. Therefore, scaling with precipitation would even worsen emission estimates. Overall, a combination of temperature and inundation extent dependences that are used in the models can explain their seasonal cycle mismatch with TROPOMI emissions.

\section{Conclusions}

$\mathrm{XCH}_{4}$ enhancements over South Sudan have been observed in remote sensing studies suggesting large emissions from the Sudd wetlands as the cause (Lunt et al., 2019; Hu et al., 2018; Frankenberg et al., 2011). We observe two large enhancements in the region on a 2-year average map of TROPOMI $\mathrm{XCH}_{4}$ - over the Sudd, Machar and Lotilla wetlands. The Sudd wetlands are flooded by the White Nile River originating from Lake Victoria, while the wetlands in the east are around smaller rivers like the Sobat originating in the Ethiopian mountains. In this study, we examine these wetlands and their river systems together to understand the controls of the emissions causing the large $\mathrm{XCH}_{4}$ enhancements.

We estimate methane emissions of $7.4 \pm 3.2 \mathrm{Tg} \mathrm{yr}^{-1}$ from wetlands in South Sudan during 2018-2019 using a mass balance approach applied to TROPOMI data. We find large differences between the emission estimates from TROPOMI and the wetland process models LPJ-wsl and Wetcharts. The annual mean estimates from TROPOMI are an order of magnitude larger than mean estimates of the models, which may be explained by the underestimated (up to 4 times) inundation extent in the models. We find differences in the interannual variability and average seasonal cycles of TROPOMI and the models, which can again be partially explained by the strong dependence of model emissions on poor inundation extent estimates. We find the lowest emission in the highest precipitation and lowest temperature season (JJA) when models estimate large emissions as they incorrectly assume an instantaneous influence of the precipitation-derived inundation extent. We find that the Wetcharts emission estimates that use a stronger temperature dependence $\left(q_{10}=3\right)$ show better agreement with TROPOMI concerning both seasonality and annual emissions. This indicates that the models may also underestimate the temperature sensitivity of the methane emissions.

The inundation extent of SSWR is analyzed using satellitealtimetry-based river height measurements of the White Nile and Sobat rivers at locations within the Sudd and Machar wetlands. The inundation extent estimates used in models are based on the local precipitation, whereas the actual inundation extent of SSWR is driven by water inflow from the rivers as evapotranspiration exceeds the precipitation in the region. As a result, both the seasonal cycle and trend of model inundation extent disagree with river height data. The seasonal cycle of inundation extent from river height data shows better agreement with the TROPOMI emissions when a full seasonlong lag between the two is assumed. This time lag can be explained by the time needed for methanogenesis to develop in the seasonally flooded areas of the wetlands. A more precise estimate of the lag is not possible due to the coarse temporal resolution of our TROPOMI emissions estimates.

The lack of information on the correct relationship of wetland emissions to inundation extent and temperature results 
in large model uncertainties. Such large gaps in our understanding of the processes driving wetland emissions call for further investigation. As shown here for the wetlands of South Sudan, TROPOMI provides valuable observations over remote and inaccessible wetland regions of the world, which future wetland studies can take advantage of. 


\section{Appendix A: Systematic measurement errors}

Surface albedo and aerosols can alter the optical light path, introducing biases in $\mathrm{XCH}_{4}$ (Butz et al., 2012). Therefore, the $\mathrm{XCH}_{4}$ enhancement over South Sudan can be affected by the differences between the source and background region values of these parameters. The average retrieved aerosol optical thickness (AOT) and surface albedo in the SWIR band of TROPOMI are shown in Fig. A1. For SSWR and its background, the AOT and albedo differences in 2-year average data are 0.001 and -0.10 , respectively. The average differences for seasonal average maps are $-0.01 \pm 0.01$, $-0.15 \pm 0.02$ and $16.3 \pm 8.4 \mathrm{ppb}$ for AOT, albedo and $\mathrm{XCH}_{4}$, respectively. The negative albedo difference for SSWR occurs due to the high albedo for the Sahara in the background. This small albedo difference is unlikely to influence the SSWR $\mathrm{XCH}_{4}$ enhancement significantly, especially as an albedo-based bias correction is applied to the $\mathrm{XCH}_{4}$ in the operational TROPOMI product (Hasekamp et al., 2019). We also examined the possibility that the $\mathrm{XCH}_{4}$ enhancement over South Sudan is an artifact of the sun-glint geometry of TROPOMI observations due to reflection from standing water in the lakes and inundated areas in the region. This can happen when the observation geometry over a water body surface is at the specular reflection angle (i.e., the viewing zenith angle matches the solar zenith angle), causing a spike in the level 1 radiance measurements. However, this was found not to occur over the wetlands of South Sudan.
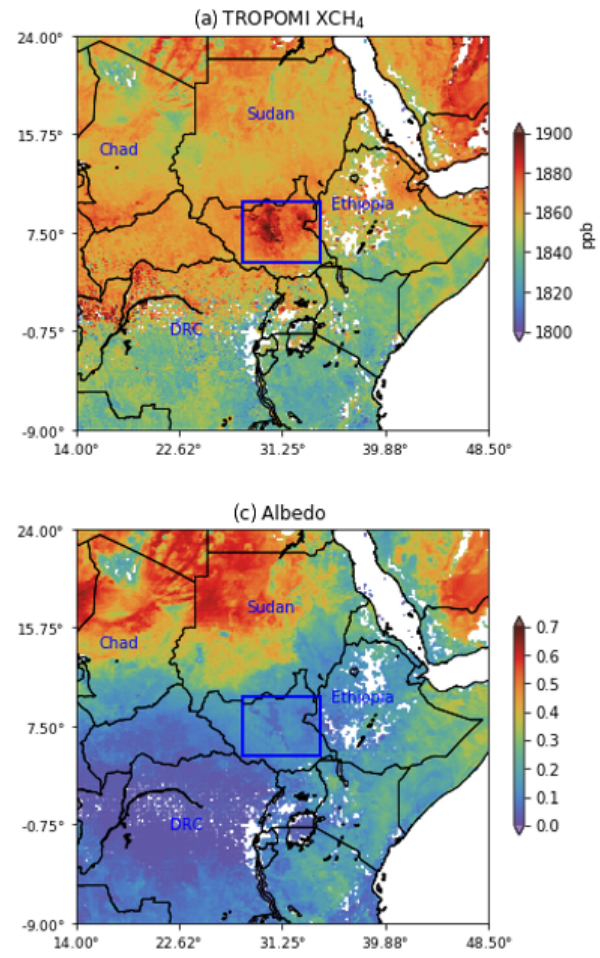

Table A1. The total of permanent SSWR inundation extent from Huges and Huges (1992).

\begin{tabular}{lr}
\hline Wetlands in SSWR & $\begin{array}{r}\text { Inundation } \\
\text { extent }\left(\mathrm{km}^{2}\right)\end{array}$ \\
\hline Sudd & 16500 \\
Machar marshes & 9000 \\
Lotilla swamps & 2000 \\
Veveno, Adiet and Lilebook & 6500 \\
Kenamuke and Kobowen swamps & 1700 \\
Bahr el Ghazal floodplains & 900 \\
\hline Total & 36000 \\
\hline
\end{tabular}
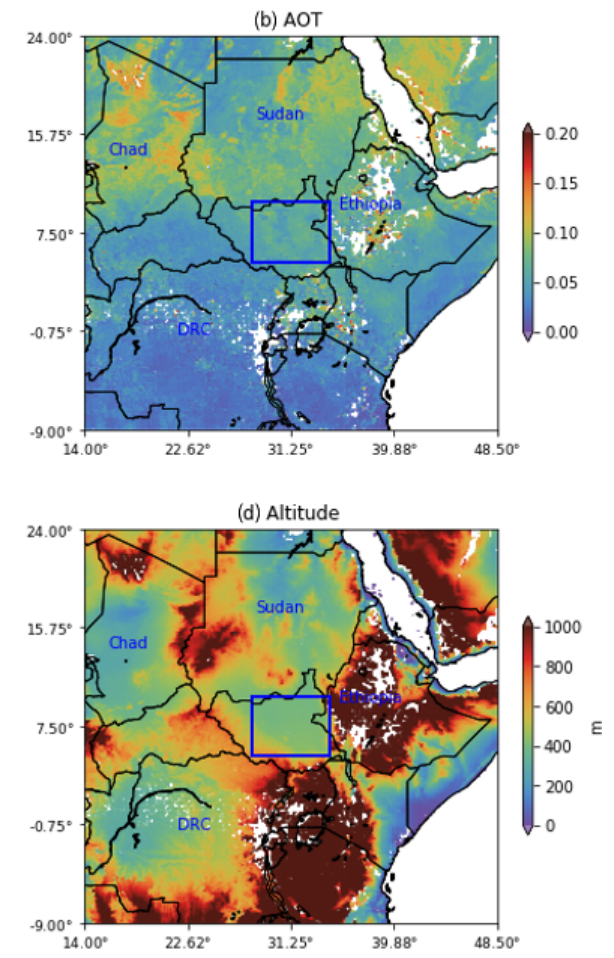

Figure A1. Average TROPOMI data (2018-2019) at $0.1^{\circ} \times 0.1^{\circ}$ resolution. The albedo and AOT are retrieved for the SWIR band at $2.3 \mu \mathrm{m}$. 
Data availability. TROPOMI data are available at the Copernicus Open Access Hub (https://s5phub.copernicus.eu/dhus/\#/home, last access: 10 January, 2021, KNMI, 2021). The satellite altimetry river height dataset is available at the Hydroweb website (http: //hydroweb.theia-land.fr/, last access: 10 January, 2021, CNES, 2021). Wetcharts data can be downloaded from https://daac.ornl. gov/CMS/guides/CMS_Global_Monthly_Wetland_CH4.html (last access: 10 January, 2021, NASA-CMS, 2021). SWAMPS inundation extent data are available at https://wetlands.jpl.nasa.gov/ cgi-bin/downloadProduct.pl?productName=fw_00_swe (Jensen et al., 2019). LPJ-wsl data are available from Zhen Zhang (yuisheng@gmail.com) upon request.

Author contributions. The study was designed by SP, IA and SH. $\mathrm{AL}$ and TB provided the TROPOMI $\mathrm{XCH}_{4}$ data. AAB provided Wetcharts data. BP and ZZ provided LPJ-wsl data. SP and MT performed the analysis. SP, IA and SH wrote the paper using contributions from all the co-authors.

Competing interests. The authors declare that they have no conflict of interest.

Acknowledgements. We thank the team that has realized TROPOMI, consisting of the partnership between Airbus Defence and Space Netherlands, the Royal Netherlands Meteorological Institute (KNMI), the SRON Netherlands Institute for Space Research (TNO), the Netherlands Organisation for Applied Scientific Research (TNO), the Netherlands Space Office (NSO), and the European Space Agency.

Financial support. This research has been supported by the Netherlands Organisation for Scientific Research (NWO) through the GALES (Gas Leaks from Space) project (grant no. 15597) by the Dutch Technology Foundation, which is part of the Netherlands Organisation for Scientific Research (NWO), and is partly funded by the Ministry of Economic Affairs, the Netherlands. Alba Lorente and Tobias Borsdorff are in part funded by the TROPOM national program from the Netherlands Space Office. Part of this research was conducted at the Jet Propulsion Laboratory, California Institute of Technology. Anthony Bloom is supported by NASA Earth Science (grant no. NNH14ZDA001N-CMS). Benjamin Poulter and Zhen Zhang are supported by the Gordon and Betty Moore Foundation (grant no. GBMF5439).

Review statement. This paper was edited by Lutz Merbold and reviewed by two anonymous referees.

\section{References}

Arneth, A., Harrison, S. P., Zaehle, S., Tsigaridis, K., Menon, S., Bartlein, P. J., Feichter, J., Korhola, A., Kulmala, M., O’Donnell, D., Schurgers, G., Sorvari, S., and Vesala, T.: Terrestrial biogeo- chemical feedbacks in the climate system, Nat. Geosci., 3, 525532, 2010.

Bloom, A. A., Palmer, P. I., Fraser, A., Reay, D. S., and Frankenberg, C.: Large-scale controls of methanogenesis inferred from methane and gravity spaceborne data, Science, 327, 322-325, 2010.

Bloom, A. A., Exbrayat, J.-F., van der Velde, I. R., Feng, L., and Williams., M.: The decadal state of the terrestrial carbon cycle: Global retrievals of terrestrial carbon allocation, pools, and residence times, P. Natl. Acad. Sci. USA, 113, 1285-1290, https://doi.org/10.1073/pnas.1515160113, 2016.

Bloom, A. A., Bowman, K. W., Lee, M., Turner, A. J., Schroeder, R., Worden, J. R., Weidner, R., McDonald, K. C., and Jacob, D. J.: A global wetland methane emissions and uncertainty dataset for atmospheric chemical transport models (WetCHARTs version 1.0), Geosci. Model Dev., 10, 2141-2156, https://doi.org/10.5194/gmd-10-2141-2017, 2017.

Bontemps, S., Defourny, P., Bogaert, E. V., Arino, O., Kalogirou, V., and Perez, J. R.: Globcover Products Description and Validation Report, Tech. rep., ESA, 2011.

Buchwitz, M., Schneising, O., Reuter, M., Heymann, J., Krautwurst, S., Bovensmann, H., Burrows, J. P., Boesch, H., Parker, R. J., Somkuti, P., Detmers, R. G., Hasekamp, O. P., Aben, I., Butz, A., Frankenberg, C., and Turner, A. J.: Satellite-derived methane hotspot emission estimates using a fast data-driven method, Atmos. Chem. Phys., 17, 5751-5774, https://doi.org/10.5194/acp-17-5751-2017, 2017.

Butz, A., Galli, A., Hasekamp, O., Landgraf, J., Tol, P., and Aben, I.: TROPOMI aboard Sentinel-5 Precursor: Prospective performance of $\left(\mathrm{CH}_{4}\right)$ retrievals for aerosol and cirrus loaded atmospheres, Remote Sens. Environ., 120, 267-276, https://doi.org/10.1016/j.rse.2011.05.030, 2012.

CNES: Time series of water levels in the rivers and lakes around the world, avialabe at: http://hydroweb.theia-land.fr/, last access: 10 January, 2021.

Crétaux, J. F., Jelinski, W., Calmant, S., Kouraev, A., Vuglinski, V., Bergé-Nguyen, M., Gennero, M. C., Nino, F., Abarca Del Rio, R., Cazenave, A., and Maisongrande, P.: SOLS: A lake database to monitor in the Near Real Time water level and storage variations from remote sensing data, Adv. Sp. Res., 47, 1497-1507, https://doi.org/10.1016/j.asr.2011.01.004, 2011.

Crippa, M., Oreggioni, G., Guizzardi, D., Muntean, M., Schaaf, E., Lo Vullo, E., Solazzo, E., Monforti-Ferrario, F., Olivier, J. G. J., Vignati, E.: Fossil $\mathrm{CO}_{2}$ and GHG emissions of all world countries - 2019 Report, EUR 29849 EN, Publications Office of the European Union, Luxembourg, ISBN 978-92-76-11100-9, 2019.

Crutzen, P. J., Aselmann, I., and Seiler, W.: Methane production by domestic animals, wild ruminants, other herbivorous fauna, and humans, Tellus B, 38, 271-284, https://doi.org/10.1111/j.16000889.1986.tb00193.x, 1986.

Da Silva, J. S., Calmant, S., Seyler, F., Rotunno Filho, O. C., Cochonneau, G., and Mansur, W. J.: Water levels in the Amazon basin derived from the ERS 2 and ENVISAT radar altimetry missions, Remote Sens. Environ., 114, 2160-2181, 2010.

Danielson, J. J. and Gesch, D. B.: Global multi-resolution terrain elevation data 2010 (GMTED2010): U.S. Geological Survey Open-File Report 2011-1073, 26 p, available at: https: //pubs.usgs.gov/of/2011/1073/pdf/of2011-1073.pdf (last access: 27 June 2020), 2011. 
FAOSTAT Online Statistical Service (Food and Agriculture Organization; FAO): available at: http://faostat3.fao.org, last access: 1 October 2020.

Frankenberg, C., Aben, I., Bergamaschi, P., Dlugokencky, E. J., van Hees, R., Houweling, S., van der Meer, P., Snel, R., and Tol, P.: Global column-averaged methane mixing ratios from 2003 to 2009 as derived from SCIAMACHY: Trends and variability, J. Geophys. Res., 116, D04302, https://doi.org/10.1029/2010JD014849, 2011.

Ganesan, A. L., Schwietzke, S., Poulter, B., Arnold, T., Lan, X., Rigby, M., Vogel, F. R., van der Werf, G. R., Janssens-Maenhout, G., Boesch, H., Pandey, S., Manning, A. J., Jackson, R. B., Nisbet, E. G., and Manning, M. R.: Advancing Scientific Understanding of the Global Methane Budget in Support of the Paris Agreement, Global Biogeochem. Cycles, 33, 1475-1512, https://doi.org/10.1029/2018GB006065, 2019.

Gumbricht, T., Roman-Cuesta, R. M., Verchot, L., Herold, M., Wittmann, F., Householder, E., Herold, N., and Murdiyarso, D.: An expert system model for mapping tropical wetlands and peatlands reveals South America as the largest contributor, Glob. Chang. Biol., 23, 3581-3599, https://doi.org/10.1111/gcb.13689, 2017.

Hasekamp, O., Lorente, A., Hu, H., Butz, A., Aan De Brugh, J., and Landgraf, J.: Algorithm Theoretical Baseline Document for Sentinel-5 Precursor Methane Retrieval, available at: https: //sentinel.esa.int/web/sentinel/home (last access: 27 June 2020), 2019.

Hersbach, H. and Dee, D.: ERA5 reanalysis is in production, ECMWF Newsletter, Vol. 147, p. 7, available at: https://www. ecmwf.int/en/newsletter/147/news/era5-reanalysis-production (last access: 27 June 2020), 2016.

Hu, H., Hasekamp, O., Butz, A., Galli, A., Landgraf, J., Aan de Brugh, J., Borsdorff, T., Scheepmaker, R., and Aben, I.: The operational methane retrieval algorithm for TROPOMI, Atmos. Meas. Tech., 9, 5423-5440, https://doi.org/10.5194/amt-9-54232016, 2016.

Hu, H., Landgraf, J., Detmers, R., Borsdorff, T., Aan de Brugh, J., Aben, I., Butz, A., and Hasekamp, O.: Toward Global Mapping of Methane With TROPOMI: First Results and Intersatellite Comparison to GOSAT, Geophys. Res. Lett., 45, 3682-3689, https://doi.org/10.1002/2018GL077259, 2018.

Hughes, R. H. and Hughes, J. S.: A Directory of African wetlands, International Union for the Conservation of Nature, Gland, Switzerland, United Nations Environment Programme, Nairobi, Kenya and World Conservation Monitoring Centre, Cambridge, UK, 1992.

Itoh, M., Sudo, S., Mori, S., Saito, H., Yoshida, T., Shiratori, Y., Suga, S., Yoshikawa, N., Suzue, Y., Mizukami, H., and Mochida, T.: Mitigation of methane emissions from paddy fields by prolonging midseason drainage. Agr. Ecosyst Environ., 141, 359372, 2011.

Janssens-Maenhout, G., Crippa, M., Guizzardi, D., Muntean, M., Schaaf, E., Dentener, F., Bergamaschi, P., Pagliari, V., Olivier, J. G. J., Peters, J. A. H. W., van Aardenne, J. A., Monni, S., Doering, U., and Petrescu, A. M. R.: EDGAR v4.3.2 Global Atlas of the three major Greenhouse Gas Emissions for the period 1970-2012, Earth Syst. Sci. Data Discuss. [preprint], https://doi.org/10.5194/essd-2017-79, 2017.
Jensen, K. and McDonald, K.: Surface Water Microwave Product Series Version 3.2, available at: https: //asf.alaska.edu/data-sets/derived-data-sets/wetlands-measures/ wetlands-measures-product-downloads/, last access: 10 January, 2021.

Jerman, V., Metje, M., Mandić-Mulec, I., and Frenzel, P.: Wetland restoration and methanogenesis: the activity of microbial populations and competition for substrates at different temperatures, Biogeosciences, 6, 1127-1138, https://doi.org/10.5194/bg6-1127-2009, 2009.

Kirschke, S., Bousquet, P., Ciais, P., Saunois, M., Canadell, J. G., Dlugokencky, E. J., Bergamaschi, P., Bergmann, D., Blake, D. R., Bruhwiler, L., Cameron-Smith, P., Castaldi, S., Chevallier, F., Feng, L., Fraser, A., Heimann, M., Hodson, E. L., Houweling, S., Josse, B., Fraser, P. J., Krummel, P. B., Lamarque, J.F., Langenfelds, R. L., Le Quéré, C., Naik, V., O’Doherty, S., Palmer, P. I., Pison, I., Plummer, D., Poulter, B., Prinn, R. G., Rigby, M., Ringeval, B., Santini, M., Schmidt, M., Shindell, D. T., Simpson, I. J., Spahni, R., Steele, L. P., Strode, S. a., Sudo, K., Szopa, S., van der Werf, G. R., Voulgarakis, A., van Weele, M., Weiss, R. F., Williams, J. E., and Zeng, G.: Three decades of global methane sources and sinks, Nat. Geosci., 6, 813-823, https://doi.org/10.1038/ngeo1955, 2013.

KNMI, SRON: TROPOMI/S5P Methane, available at: https: //s5phub.copernicus.eu/dhus/\#/home, last access: 10 January 2021.

Lehner, B. and Döll, P.: Development and validation of a global database of lakes, reservoirs, and wetlands, J. Hydrol., 296, 122, https://doi.org/10.1016/j.jhydrol.2004.03.028, 2004.

Lunt, M. F., Palmer, P. I., Feng, L., Taylor, C. M., Boesch, H., and Parker, R. J.: An increase in methane emissions from tropical Africa between 2010 and 2016 inferred from satellite data, Atmos. Chem. Phys., 19, 14721-14740, https://doi.org/10.5194/acp-19-14721-2019, 2019.

NASA-CMS: Global 0.5-deg Wetland Methane Emissions and Uncertainty (WetCHARTs v1.0)m available at: https://daac.ornl. gov/CMS/guides/CMS_Global_Monthly_Wetland_CH4.html, last access: 10 January, 2021.

Pandey, S., Houweling, S., Krol, M., Aben, I., Monteil, G., NechitaBanda, N., Dlugokencky, E. J., Detmers, R., Hasekamp, O., Xu, X., Riley, W. J., Poulter, B., Zhang, Z., McDonald, K. C., White, J. W. C., Bousquet, P., and Röckmann, T.: Enhanced methane emissions from tropical wetlands during the 2011 la Niña, Sci. Rep.-UK, 7, 1-8, https://doi.org/10.1038/srep45759, 2017.

Rebelo, L.-M., Senay, G. B., and McCartney, M. P.: Flood Pulsing in the Sudd Wetland: Analysis of Seasonal Variations in Inundation and Evaporation in South Sudan, Earth Interact., 16, 1-19, https://doi.org/10.1175/2011ei382.1, 2012.

Ringeval, B., De Noblet-Ducoudré, N., Ciais, P., Bousquet, P., Prigent, C., Papa, F. and Rossow, W. B.: An attempt to quantify the impact of changes in wetland extent on methane emissions on the seasonal and interannual time scales, Global Biogeochem. Cy., 24, GB2003, https://doi.org/10.1029/2008GB003354, 2010.

Saunois, M., Bousquet, P., Poulter, B., Peregon, A., Ciais, P., Canadell, J. G., Dlugokencky, E. J., Etiope, G., Bastviken, D., Houweling, S., Janssens-Maenhout, G., Tubiello, F. N., Castaldi, S., Jackson, R. B., Alexe, M., Arora, V. K., Beerling, D. J., Bergamaschi, P., Blake, D. R., Brailsford, G., Brovkin, V., Bruhwiler, L., Crevoisier, C., Crill, P., Covey, K., Curry, C., Frankenberg, C., 
Gedney, N., Höglund-Isaksson, L., Ishizawa, M., Ito, A., Joos, F., Kim, H.-S., Kleinen, T., Krummel, P., Lamarque, J.-F., Langenfelds, R., Locatelli, R., Machida, T., Maksyutov, S., McDonald, K. C., Marshall, J., Melton, J. R., Morino, I., Naik, V., O’Doherty, S., Parmentier, F.-J. W., Patra, P. K., Peng, C., Peng, S., Peters, G. P., Pison, I., Prigent, C., Prinn, R., Ramonet, M., Riley, W. J., Saito, M., Santini, M., Schroeder, R., Simpson, I. J., Spahni, R., Steele, P., Takizawa, A., Thornton, B. F., Tian, H., Tohjima, Y., Viovy, N., Voulgarakis, A., van Weele, M., van der Werf, G. R., Weiss, R., Wiedinmyer, C., Wilton, D. J., Wiltshire, A., Worthy, D., Wunch, D., Xu, X., Yoshida, Y., Zhang, B., Zhang, Z., and Zhu, Q.: The global methane budget 2000-2012, Earth Syst. Sci. Data, 8, 697-751, https://doi.org/10.5194/essd-8-697-2016, 2016.

Sanderson, M. G.: Biomass of termites and their emissions of methane and carbon dioxide: A global database, Global Biogeochem. Cy., 10, 543-557, https://doi.org/10.1029/96gb01893, 1996.

Scarpelli, T. R., Jacob, D. J., Maasakkers, J. D., Sulprizio, M. P., Sheng, J.-X., Rose, K., Romeo, L., Worden, J. R., and JanssensMaenhout, G.: A global gridded $\left(0.1^{\circ} \times 0.1^{\circ}\right)$ inventory of methane emissions from oil, gas, and coal exploitation based on national reports to the United Nations Framework Convention on Climate Change, Earth Syst. Sci. Data, 12, 563-575, https://doi.org/10.5194/essd-12-563-2020, 2020.

Schroeder, R., McDonald, K., Chapman, B., Jensen, K., Podest, E., Tessler, Z., Bohn, T., and Zimmermann, R.: Development and evaluation of a multiyear fractional surface water data set derived from active/passive microwave remote sensing data, Remote Sens., 7, 16688-16732, https://doi.org/10.3390/rs71215843, 2015.

Sutcliffe, J. and Brown, E.: Water losses from the Sudd, Hydrol. Sci. J., 63, 527-541, https://doi.org/10.1080/02626667.2018.1438612, 2018.

Travaglia C, McDaid Kapetsky J., and Righini G.: Monitoring wetlands for fisheries by NOAA AVHRR LAC thermal data, SC Series (FAO), 1995.

Tunnicliffe, R. L., Ganesan, A. L., Parker, R. J., Boesch, H., Gedney, N., Poulter, B., Zhang, Z., Lavrič, J. V., Walter, D., Rigby, M., Henne, S., Young, D., and O'Doherty, S.: Quantifying sources of Brazil's $\mathrm{CH}_{4}$ emissions between 2010 and 2018 from satellite data, Atmos. Chem. Phys., 20, 13041-13067, https://doi.org/10.5194/acp-20-13041-2020, 2020.

van der Werf, G. R., Randerson, J. T., Giglio, L., van Leeuwen, T. T., Chen, Y., Rogers, B. M., Mu, M., van Marle, M. J. E., Morton, D. C., Collatz, G. J., Yokelson, R. J., and Kasibhatla, P. S.: Global fire emissions estimates during 1997-2016, Earth Syst. Sci. Data, 9, 697-720, https://doi.org/10.5194/essd-9-697-2017, 2017.
Varon, D. J., Jacob, D. J., McKeever, J., Jervis, D., Durak, B. O. A., Xia, Y., and Huang, Y.: Quantifying methane point sources from fine-scale satellite observations of atmospheric methane plumes, Atmos. Meas. Tech., 11, 5673-5686, https://doi.org/10.5194/amt-11-5673-2018, 2018.

Veefkind, J. P., Aben, I., McMullan, K., Förster, H., de Vries, J., Otter, G., Claas, J., Eskes, H. J., de Haan, J. F., Kleipool, Q., van Weele, M., Hasekamp, O., Hoogeveen, R., Landgraf, J., Snel, R., Tol, P., Ingmann, P., Voors, R., Kruizinga, B., Vink, R., Visser, H., and Levelt, P. F.: TROPOMI on the ESA Sentinel-5 Precursor: A GMES mission for global observations of the atmospheric composition for climate, air quality and ozone layer applications, Remote Sens. Environ., 120, 70-83, https://doi.org/10.1016/j.rse.2011.09.027, 2012.

Wilson, C., Gloor, M., Gatti, L. V., Miller, J. B., Monks, S. A., McNorton, J., Bloom, A. A., Basso, L. S., and Chipperfield, M. P.: Contribution of regional sources to atmospheric methane over the Amazon Basin in 2010 and 2011, Global Biogeochem. Cy., 30, 22-23, https://doi.org/10.1002/2015GB005300, 2016.

Zhang, Z., Zimmermann, N. E., Kaplan, J. O., and Poulter, B.: Modeling spatiotemporal dynamics of global wetlands: comprehensive evaluation of a new sub-grid TOPMODEL parameterization and uncertainties, Biogeosciences, 13, 1387-1408, https://doi.org/10.5194/bg-13-1387-2016, 2016.

Zhang, Z., Zimmermann, N. E., Stenke, A., Li, X., Hodson, E. L., Zhu, G., Huang, C., and Poulter, B.: Emerging role of wetland methane emissions in driving 21 st century climate change, P. Natl. Acad. Sci. USA, 114, 9647-9652, https://doi.org/10.1073/pnas.1618765114, 2017.

Zhang, Z., Zimmermann, N. E., Calle, L., Hurtt, G., Chatterjee, A., and Poulter, B.: Enhanced response of global wetland methane emissions to the 2015-2016 El Niño-Southern Oscillation event, Environ. Res. Lett., 13, 7, https://doi.org/10.1088/17489326/aac939, 2018.

Zhang, Y., Gautam, R., Pandey, S., Omara, M., Maasakkers, J. D., Sadavarte, P., Lyon, D., Nesser, H., Sulprizio, M. P., Varon, D. J., Zhang, R., Houweling, S., Zavala-Araiza, D., Alvarez, R. A., Lorente, A., Hamburg, S. P., Aben, I., and Jacob, D. J.: Quantifying methane emissions from the largest oil-producing basin in the United States from space, Sci. Adv., 6, eaaz5120, https://doi.org/10.1126/sciadv.aaz5120, 2020.

Zhu, Q., Peng, C., Ciais, P., Jiang, H., Liu, J., Bousquet, P., Li, S., Chang, J., Fang, X., Zhou, X., Chen, H., Liu, S., Lin, G., Gong, P., Wang, M., Wang, H., Xiang, W., and Chen, J.: Interannual variation in methane emissions from tropical wetlands triggered by repeated El Niño Southern Oscillation, Glob. Chang. Biol., 23, 4706-4716, https://doi.org/10.1111/gcb.13726, 2017. 